Gazi University
Journal of Science
$\mathrm{http} / /$ dergipark.gov.tr/gujs

\title{
Various Mechanical Properties of Denture Liners Combined with Zirconium Oxide Nanoparticles
}

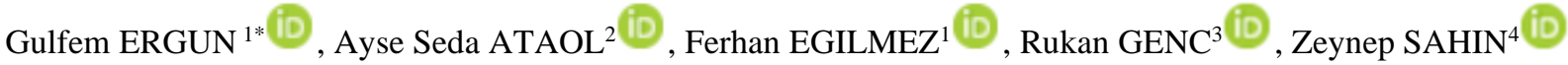 \\ ${ }^{I}$ Gazi University, Faculty of Dentistry, Department of Prosthodontics, 06510, Ankara, Turkey \\ ${ }^{2}$ Ankara Medipol University, Faculty of Dentistry, Department of Prosthodontics, 06510, Ankara, Turkey \\ ${ }^{3}$ Mersin University, Faculty of Engineering, Department of Chemical Engineering, 33110, Mersin, Turkey \\ ${ }^{4}$ Lokman Hekim University, Faculty of Dentistry, Department of Prosthodontics, 06510, Ankara, Turkey \\ Highlights \\ - This paper focuses on nanomaterials to enhance the quality of polymers. \\ - Investigation for the effect of adding various $\mathrm{ZrO}_{2}$ nanoparticle ratios to denture liners. \\ - To make inferences about the clinical use of $\mathrm{ZrO}_{2}-\mathrm{NPs}$ added prosthetic lining materials.
}

Article Info

Received: 06 July 2020

Accepted: 12 Feb 2021

\section{Keywords}

\section{Zirconium oxide}

Nanoparticles

Soft denture liner

Tissue conditioner

Mechanical properties

\begin{abstract}
Debonding from the denture base, poor resistance to tearing, and increase in hardness are some of the problems with denture liners. This research purposed to analyze the changes in mechanical characteristics of the tissue conditioner and the denture liner concerning the interaction of the material with the zirconium oxide nanoparticles $\left(\mathrm{ZrO}_{2}-\mathrm{NPs}\right)$. The surface functionalization of $\mathrm{ZrO}_{2}$-NPs was done using a silane coupling agent as a modifier for better integration of them into the denture liners. Then, they were added into acrylic- and silicone-based denture liner in two different percentages $(0.5 \%$ and $1 \%$ by weight; respectively). The performed tests were tear strength, tensile bond strength, and hardness (Shore A). $0.5 \%$ and $1 \%$ of $\mathrm{ZrO}_{2}-\mathrm{NPs}$ added tissue conditioner test groups displayed statistically significantly lower tensile bond strength values than tissue conditioners without $\mathrm{ZrO}_{2}-\mathrm{NPs}(\mathrm{p}<0.001)$. However, the tensile bond strength results of all subgroups for soft denture liner were statistically similar $(p=0.239)$. In all of the test groups of tissue conditioner and soft lining material, the highest tear strength values were obtained in $0.5 \% \mathrm{ZrO}_{2}$-NPs added test groups (tissue conditioner; $0.58 \pm 0.11 \mathrm{~N}$ and soft denture liner; $4.10 \pm 0.58 \mathrm{~N})$. The shore A hardness results of both tested groups determined no meaningful differences $(p=0.100)$. All subgroups of the tested silicone-based denture liners had satisfactory and clinically adequate bonding strength to the base of the prosthetic.
\end{abstract}

\section{INTRODUCTION}

Resilient lining materials are generally preferred for patients with a removable prosthesis to disperse masticatory loads equally over the tissue surface of dentures [1]. Additionally, they are viscoelastic materials that act as shock absorbers [2]. The soft denture liners (SDLs) have the capability of enhancing comfort to denture patients with alveolar ridge resorption, bruxism, thin and non-resilient mucosal tissues as well as bony undercuts [3-4]. These materials are also recommended in case of edentulous arches against natural teeth [5], reconstruction of congenital, acquired, or developmental maxillofacial defects, and healing after implant placement [6].

The denture liners are categorized as acrylic and silicone-based lining materials $[4,7]$. There are two types of self-cured and heat-cured forms [8]. According to other classifications, resilient lining materials may be classified as short-term (healing liners) and permanent soft liners [7]. Moreover, healing liners or tissue conditioners (TCs) are utilized immediately after surgery [9]. TCs usually include powder and liquid [2]. 
They can be used for a few days or a week. Besides, silicone-based lining materials may need to be used for about a year [9].

The desirable attributes for denture liners are great dimensional stability, acceptable resistance to tearing, permanent softness or resilience. In addition, they have no smell or taste with a simple cleaning procedure and a strong adherence to the denture base. They are also biologically compatible [10-11]. Many prosthetic lining materials have been used until today. Some of them are plasticized acrylic, vinyl polymers, copolymers, fluoroelastomer, silicon rubber, and natural rubber. Even though various features of denture liners have already been developed, no ideal material has yet been found to meet all requirements [9]. The porosity, increased hardness, debonding from the base of the prosthesis, accumulation of microorganisms, and low tear strength are some problems with the clinical usage of denture liners $[4,12]$. For that reason, periodic evaluation and replacement of these materials are of high importance [9]. Debonding from the denture base is among the most important problems encountered in denture liners [13]. Several techniques are applied to improve the bonding strength between denture liners and denture base. Previous works have investigated the creation of roughness at the acrylic tissue surface through alumina abrasion, lasers, chemical etching [13], and acrylic burs [3-4].

Another problem related to denture liners is the growth of microorganisms [9,14]. The most frequently investigated antimicrobial agents, which are incorporated into denture liners for preventing microbial accumulation, are additives such as nystatin, ketoconazole, chlorhexidine, miconazole, itraconazole, magnesium oxide [15].

Nanotechnology is known to be one of the most actual research areas as far as materials science is concerned [16]. Particles with a size of up to $100 \mathrm{~nm}$ are classified as nanoparticles. In addition, they present advanced properties when compared to the bigger particles [17]. The differences based on specific properties are distribution, size, and morphology [16-17]. Additionally, studies have shown that the addition of silver nanoparticles into denture liners has antimicrobial effects $[14,18,19]$.

Recent studies on nanomaterials have increased to strengthen the mechanical attributes of denture base polymers [20]. There is a good deal of research performed on the enhancement of the mechanical features of denture base with the incorporation of zirconium oxide nanoparticles $\left(\mathrm{ZrO}_{2}-\mathrm{NPs}\right)$ as a filler [20-23]. $\mathrm{ZrO}_{2}$ has native color, high strength, good chemical stability, chemical and microbial resistance [24]. Since $\mathrm{ZrO}_{2}$-NPs has excellent mechanical properties and the highest hardness among any oxide, it prevents the propagation of the crack [22].

The chemical activity, high specific surface area and surface energy of nanoparticles result in strong aggregation. This clustering causes a decrease in the interaction between particle and polymer, thus the reinforcement effect on the PMMA matrix decreases [20]. Sufficient adhesion, as well as a homogeneous dispersion, of $\mathrm{ZrO}_{2}$-NPs into a resin matrix improve the mechanical features of a polymer/nanoparticle structure [23].

To the authors' knowledge, there is little information regarding the impacts of $\mathrm{ZrO}_{2}-\mathrm{NPs}$ incorporation on certain physical and mechanical attributes of denture liners in the literature. The present study aims to research the impacts of $\mathrm{ZrO}_{2}-\mathrm{NPs}$ addition upon the hardness of two different denture liners apart from tear strength and tensile bond strength (TBS). We hypothesize that the addition of $\mathrm{ZrO}_{2}-\mathrm{NPs}$ improves TBS and tear strength of various denture liners. Furthermore, the addition of $\mathrm{ZrO}_{2}-\mathrm{NPs}$ does not affect hardness negatively. 


\section{MATERIAL and METHODS}

$\mathrm{ZrO}_{2}$-NPs were synthesized from zirconium (IV) isopropoxide isopropanol complex (99.9\%, Aldrich) in anhydrous benzyl alcohol $(\geq 99 \%)$ by the solvothermal reaction according to the procedure described elsewhere [25].

\subsection{Surface Functionalization of $\mathrm{ZrO}_{2}$-NPs Using Silane Coupling Agent}

For the first modification stage, the as-synthesized $\mathrm{ZrO}_{2}-\mathrm{NPs}$ suspension was taken off the reactor. Then, a silane coupling agent (SCA) (3-aminopropyltriethoxysilane, APTES, Sigma-Aldrich) [45\% (by mass) relative to $\mathrm{ZrO}_{2}$ ] was added into the white suspension, then the mixture was heated up to $110^{\circ} \mathrm{C}$ and the reaction continued by stirring at this temperature for $12 \mathrm{~h}$. After the reaction, $\mathrm{ZrO}_{2}-\mathrm{NPs}$ modified with the SCA ( $\mathrm{ZrO}_{2}$-NPs-silane) were precipitated from the formed clear yellow liquid by adding ethyl acetate, and then the suspension was centrifuged (6280 rcf, 10 minutes). The precipitate that was obtained was dispersed in ethanol, re-precipitated with ethyl acetate, and finally centrifuged. These cycles were repeated 3 times in a row. By this process, excess SCAs and possible by-products of the reaction were removed from this precipitate. After that, the $\mathrm{ZrO}_{2}$-NPs -silane was stored in ethanol at room temperature before the next modification.

In the current study, a SCA was used to provide a double bond on the surface of $\mathrm{ZrO}_{2}$-NPs and the distribution of $\mathrm{ZrO}_{2}-\mathrm{NPs}$ fillers in the SDLs. Toluene ( $\geq 99,7 \%$, Sigma-Aldrich) was used as an organic solvent.

Pure toluene solvent in the amount of $5 \mathrm{~mL}$, and $\mathrm{ZrO}_{2}-\mathrm{NPs}$ in the amount of $250 \mathrm{mg}$ were placed into a glass beaker and ultrasonicated for $20 \mathrm{~min}$. The beaker was placed on a magnetic stirrer (Wise Stir MSH20A, stirring speed $0-1500 \mathrm{rpm}$ ). Then, $13.21 \mu \mathrm{L}$ of silane was added by using a sterile syringe under a rapid stirrer. The slurry was left for two days with the beaker covered. After that, the slurry was placed in a rotary evaporator (Buchi Rotavapor R-210) with a rotation speed of $150 \mathrm{rpm}$ for $30 \mathrm{~min}$, and exposed to a vacuum at $60^{\circ} \mathrm{C}$. Finally, the silanated $\mathrm{ZrO}_{2}$-NPs particles were made moisture-free by placing them in a vacuum oven (Binder vacuum drying model VD 53, Tuttlingen, Germany) for 20 hours at $60^{\circ} \mathrm{C}$, and then they were stored at room temperature $\left(21^{\circ} \mathrm{C}\right)$ before usage.

\subsection{The FT-IR Measurements}

Silanation of $\mathrm{ZrO}_{2}-\mathrm{NPs}$ was investigated since the integration of them to the dental materials is directly affected by this step. The measurements were performed on a Fourier-transformed infrared (FT-IR) spectrometer (Perkin Elmer Frontier, Waltham, MA, USA). Recording of 40 scans was achieved with the spectral range of 450-4000 $\mathrm{cm}^{-1}$ using the OMNIC Spectra Software. The spectral resolution was $1 \mathrm{~cm}^{-1}$.

\subsection{Preparation of Test Specimens}

\subsubsection{Addition of $\mathrm{ZrO}_{2}$-NPs filler to various denture liners}

In the current study, one silicone-based SDL (Ufi Gel P; VOCO GmbH, Cuxhaven, Germany) and one acrylic-based TC (Visco-gel, Dentsply DeTrey GmbH, Konstanz, Germany) were used. As is displayed in Table 1, the study was carried out with three test groups. Doses of $\mathrm{ZrO}_{2}-\mathrm{NPs}$ added to the tested materials are shown in Table 2. 
Table 1. The materials tested in the present study

\begin{tabular}{|c|c|c|c|c|}
\hline Brand Name & Material Type & Main Composition & Lot No. & Manufacturer \\
\hline $\begin{array}{l}\text { Group VG } \\
\text { (Visco-gel) }\end{array}$ & $\begin{array}{l}\text { auto-polymerized } \\
\text { acrylic-based } \\
\text { tissue conditioner }\end{array}$ & $\begin{array}{l}\text { Polymer: Polyethyl methacrylate } \\
\text { Solvent: Ethanol } \\
\text { Plasticizer: Butyl phthalyl butyl } \\
\text { glycolate, Dibutyl phthalate }\end{array}$ & 1610000172 & $\begin{array}{l}\text { Dentsply DeTrey } \\
\text { GmbH, } \\
\text { Konstanz, Germany }\end{array}$ \\
\hline $\begin{array}{l}\text { Group UGP } \\
\text { (Ufi Gel P) }\end{array}$ & $\begin{array}{l}\text { auto-polymerized } \\
\text { silicone-based } \\
\text { denture liner }\end{array}$ & $\begin{array}{l}\text { Modified polydimethylsiloxane } \\
\text { Platinum catalyst }\end{array}$ & 1645226 & $\begin{array}{l}\text { VOCO Gmbh, } \\
\text { Cuxhaven, } \\
\text { Germany }\end{array}$ \\
\hline $\begin{array}{l}\text { Denture base } \\
\text { material } \\
\text { (Meliodent) }\end{array}$ & $\begin{array}{l}\text { Denture base } \\
\text { polymer, heat- } \\
\text { cured, } \\
\text { Powder and liquid }\end{array}$ & $\begin{array}{l}\text { Powder: polymethyl } \\
\text { methacrylate } \\
\text { Liquid: methyl methacrylate, } \\
\text { The cross-linking agent: } \\
\text { ethylene glycol dimethacrylate }\end{array}$ & R010023 & $\begin{array}{l}\text { Heraeus Kulzer, } \\
\text { Hanau, } \\
\text { Germany }\end{array}$ \\
\hline
\end{tabular}

Table 2. Descriptions and groups of tested denture liner materials

\begin{tabular}{|c|c|c|c|c|c|}
\hline \multirow[t]{2}{*}{ Groups } & \multirow[t]{2}{*}{ Subgroups } & \multirow[t]{2}{*}{ Description } & \multicolumn{3}{|c|}{ Mixing ratio } \\
\hline & & & $\begin{array}{l}\text { Base or } \\
\text { powder }\end{array}$ & $\begin{array}{l}\text { Catalyst or } \\
\text { liquid }\end{array}$ & $\begin{array}{l}\mathrm{ZrO}_{2} \\
\mathrm{NPs}\end{array}$ \\
\hline \multirow{3}{*}{$\begin{array}{l}\text { Group UGP } \\
\text { (Ufi Gel P) }\end{array}$} & $\begin{array}{l}\text { Group } \\
\text { UGP0 }\end{array}$ & SDL without additives as control & $0.1 \mathrm{~g}$ & $0.1 \mathrm{~g}$ & - \\
\hline & $\begin{array}{l}\text { Group } \\
\text { UGP1 }\end{array}$ & SDL with $0.5 \% \mathrm{ZrO}_{2}-\mathrm{NPs}$ powder & $0.1 \mathrm{~g}$ & $0.1 \mathrm{~g}$ & $1 \mathrm{mg}$ \\
\hline & $\begin{array}{l}\text { Group } \\
\text { UGP2 }\end{array}$ & SDL with $1 \% \mathrm{ZrO}_{2}$-NPs powder & $0.1 \mathrm{~g}$ & $0.1 \mathrm{~g}$ & $2 \mathrm{mg}$ \\
\hline \multirow{3}{*}{$\begin{array}{l}\text { Group VG } \\
\text { (Visco-gel) }\end{array}$} & $\begin{array}{l}\text { Group } \\
\text { VG0 }\end{array}$ & TC without additives as control & $0.2 \mathrm{~g}$ & $146.6 \mu 1$ & - \\
\hline & $\begin{array}{l}\text { Group } \\
\text { VG1 }\end{array}$ & TC with $0.5 \% \mathrm{ZrO}_{2}$-NPs powder & $0.2 \mathrm{~g}$ & $146.6 \mu 1$ & $1 \mathrm{mg}$ \\
\hline & $\begin{array}{l}\text { Group } \\
\text { VG2 }\end{array}$ & TC with $1 \% \mathrm{ZrO}_{2}$-NPs powder & $0.2 \mathrm{~g}$ & $146.6 \mu 1$ & $2 \mathrm{mg}$ \\
\hline
\end{tabular}

(Soft denture liner: SDL, Tissue conditioner: TC)

\subsubsection{Addition of $\mathrm{ZrO}_{2}$-NPs filler to soft denture liner}

The addition of modified $\mathrm{ZrO}_{2}$-NPs was done in two groups: $0.5 \%$ and $1 \%$ by weight. Hexane solvent and modified $\mathrm{ZrO}_{2}$-NPs were placed into a glass beaker and ultrasonicated for 20 min for separating them into individual nanoparticles. After that, the catalyst of the test material was added to the mixture and ultrasonicated for $20 \mathrm{~min}$. The hexane was then evaporated at room temperature. The catalyst and modified 
$\mathrm{ZrO}_{2}$-NPs were mixed with the base of the material. The mixed ratio used for Group UGP (Ufi Gel P) was (1:1) (equal weight) done according to the instructions of the manufacturer.

\subsubsection{Addition of $\mathrm{ZrO}_{2}$-NPs filler to tissue conditioner}

The method is the same as the one mentioned above (addition of $\mathrm{ZrO}_{2}-\mathrm{NPs}$ filler to SDL). The liquid of the test material and modified $\mathrm{ZrO}_{2}$-NPs were mixed with the powder of the material. The mixed ratio used for Group VG (Visco-gel) was (3 g: $2.2 \mathrm{ml})$ done in the line with the instructions of the manufacturer.

\subsection{Tear Strength Test}

The test specimens were produced in the size of 50x10x1 mm. Each of the test specimens was cut with \#15 blade to create trouser leg shapes. Following this procedure, the legs of the specimens were inserted vertically facing in opposite directions to determine the tearing strength. The tear strength test took place on a universal machine (Shimadzu AGS-X, Tokyo, Japan) with a crosshead speed of $50 \mathrm{~mm} / \mathrm{min}$. The following formula was used to measure tear strength values

$T=\frac{F}{A}$

where $\mathrm{T}=$ stress $\left(\mathrm{N} / \mathrm{mm}^{2}\right), \mathrm{F}=$ maximum recorded force at failure $(\mathrm{N})$, and $\mathrm{A}=$ cross-sectional area $\left(\mathrm{mm}^{2}\right)$.

\subsection{Tensile Bond Strength Test}

The International Standard Organization (ISO) 10139-2 method is used to determine the TBS between the materials that are tested and the denture base resin [26]. Traditional heat-cured PMMA resins (Meliodent, Heraeus Kulzer, Hanau, Germany) were produced in a plate shape (dimension of $25 \pm 3 \mathrm{~mm}^{2}$ and $3 \pm 0.5 \mathrm{~mm}$ in thickness). Afterward, PMMA resin was stirred and packed into a mold of the dental stone cast as was recommended by the manufacturer. The plates were preliminarily ground on abrasive papers in the grit size of 200 and 400 to standardize the plates' surface. The surface of the test specimens was rinsed first and then dried for $15 \mathrm{~s}$ with air. A silicone-based adhesive (Ufi Gel SC-VOCO: Cuxhaven, Germany) had been applied using a brush on the PMMA resin plate for silicone-based denture liner test groups. On the other hand, tissue-conditioning test materials (VG0, VG1, and VG2) were applied directly without any adhesive to the surface of the acrylic plate. After that, a polyethylene ring $(10 \mathrm{~mm}$, inner diameter; and $3 \mathrm{~mm}$ thickness) was put in the middle of the plate. The slight excess of the mixed SDL was applied to the adhesive surface of the acrylic resin plates within the polyethylene ring. Another acrylic plate was placed on the test material, and then the plates were clamped during the setting for 1 hour. By the time an hour passed after the application of the soft material to the denture base, the bonded specimen was placed into the water bath at $37^{\circ} \mathrm{C}$ for $23 \pm 1 \mathrm{~h}$. The specimen was transferred to a tensile testing machine immediately after it had been taken from the water bath.

The TBS testing was carried out with a universal testing machine (Shimadzu AGS-X, Tokyo, Japan) at a crosshead speed of $10 \mathrm{~mm} / \mathrm{min}$. This test was applied until separation occurred. The TBS values of the test groups were found as maximum load $(\mathrm{N})$ divided by the bonding surface area between the test materials and PMMA resin $\left(\mathrm{mm}^{2}\right)$. The obtained value was recorded as megapascal (MPa)

$B=\frac{F m a x}{A}$

where B stands for the tensile bond strength (MPa), F stands for the maximum load (N), and A stands for the adhesive area $\left(\mathrm{mm}^{2}\right)$. 


\subsection{Shore A Hardness Test}

The hardness was measured on the top surface of the specimen using a Shore A Durometer (Zwick Roell, Germany) according to the ISO (10139-2) standards. Three test specimens of each test group (diameter, 35 $\mathrm{mm}$; thickness, $6 \mathrm{~mm}$ ) were prepared for the hardness test according to the manufacturers' instructions. The test specimens were aged in distilled water at $37 \pm 1{ }^{\circ} \mathrm{C}$ before the hardness was measured. The test was carried out under a $50 \mathrm{gf}$ load. Five different points, at least $5 \mathrm{~mm}$ from the edge of each specimen, were measured in order to determine the hardness of test specimens. The distance between the measurement places should be at least $2 \mathrm{~mm}$. After the measurements were completed, the mean values of hardness were calculated.

\subsection{SEM Analysis}

Two test specimens from hardness test groups were randomly chosen for examination under Scanning Electron Microscope (SEM) (Zeiss, SUPRA-55, Carl Zeiss NTS GmbH, Oberkochen, Germany). These specimens were made conductive under the vacuum of 10-1 mbar/Pa and a current of $10 \mathrm{~mA}$ in the goldpalladium coating unit (Quorum Q 150 R ES DC Sputter, Kent, UK) by coating with Au-Pd for 180 seconds. After coating, SEM analysis was done at x50, x100, x200 magnifications. SEM analysis was used to investigate the distribution of $\mathrm{ZrO}_{2}-\mathrm{NPs}$ in the tested denture liners.

\subsection{Statistical Analysis}

The entry and analysis of the data were carried out by using IBM SPSS Statistics version 17.0 software (IBM Corporation, Armonk, NY, USA). The evaluation of continuous variables was first performed for normality and homogeneity by Kolmogorov Smirnov and Levene's tests, respectively. Mean \pm standard deviation (SD) or median (IQR) were calculated. The average differences between the groups were compared using the Student's t test Besides, a comparison of each evaluated test parameter was performed with the Mann-Whitney $U$ test. When the number of independent groups was $>2$, data analyses were subjected to one-way analysis of variance (ANOVA) or the Kruskal-Wallis test. Post-hoc Tukey HSD or Conover's multiple comparison test was used to know which group is different from the other. A p value $<0.05$ was accepted to be statistically significant. However, Type I errors of all possible multiple comparisons were controlled using the Bonferroni correction.

\section{RESULTS AND DISCUSSION}

\subsection{Results}

\subsubsection{FT-IR analysis of silanated $\mathrm{ZrO}_{2}-\mathrm{NPs}$}

Peaks from $\mathrm{ZrO}_{2}$-NPs and silane are marked in red and black respectively in Figure 1. For the modified $\mathrm{ZrO} 2-\mathrm{NPs}$, a broad peak at $3,341 \mathrm{~cm}^{-1}$ could correspond to the $\mathrm{OH}$-stretching vibration onto the $\mathrm{ZrO}_{2}$ surface. The two strong peaks at 2,980 and $2,885 \mathrm{~cm}^{-1}$ may result from the stretching vibration of $\mathrm{C}-\mathrm{H}$ in silane. The peaks seen at 1,457 and $1,388 \mathrm{~cm}^{-1}$ represent the $\mathrm{C}-\mathrm{H}$ bending vibration. Alkaline groups (3000$2800 \mathrm{~cm}^{-1}$ ) presented on SCA was also observed on modified $\mathrm{ZrO}_{2}-\mathrm{NPs}$. The $\mathrm{Zr}-\mathrm{O}$ stretching vibration peak at $579 \mathrm{~cm}^{-1}$ could be seen in $\mathrm{ZrO}_{2}-\mathrm{NPs}$ shifts to a longer wavelength $\left(594 \mathrm{~cm}^{-1}\right)$ after modification. Furthermore, the oxygen-bearing functional groups between 1000 and $1400 \mathrm{~cm}^{-1}$ can be observed in both silane and $\mathrm{ZrO}_{2}-\mathrm{NPs}$ after modification. Si-O vibrations between $1250-900 \mathrm{~cm}^{1}$ can be contributed to the successful silanization of the particle surface (Figure 2). 


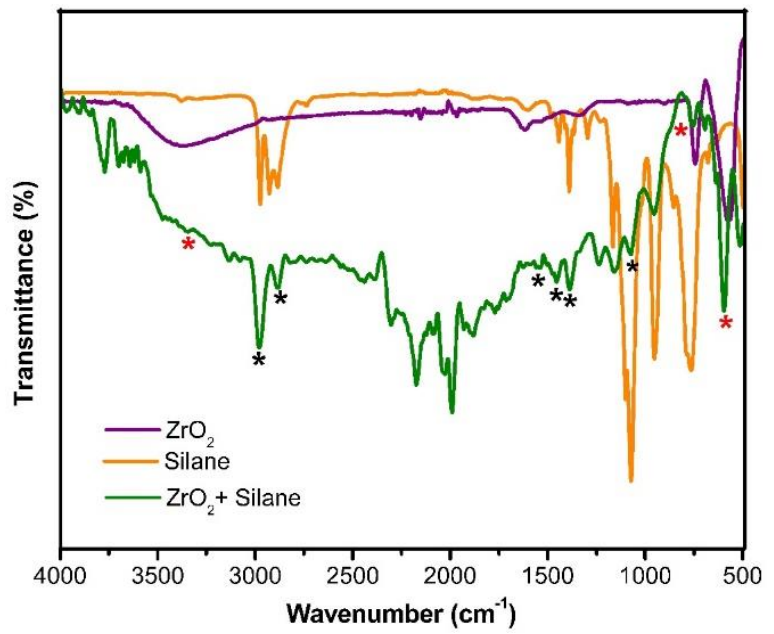

Figure 1. The infrared spectra of $\mathrm{ZrO}_{2}-\mathrm{NPs}$, silane, and modified $\mathrm{ZrO}_{2}-\mathrm{NPs}$ with silane
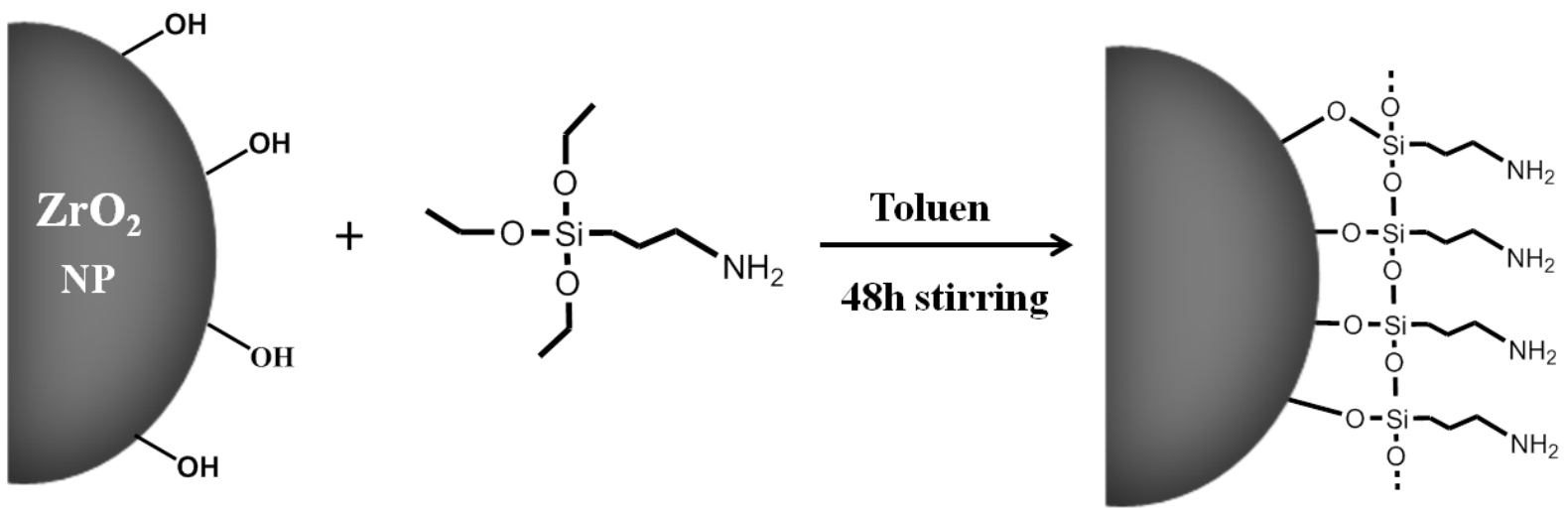

Figure 2. The schematic view of bonding between $\mathrm{ZrO}_{2}$-NPs and silane coupling agent

\subsubsection{Tear strength test}

The mean values of the tear strength for both the tested groups are presented in Table 3. In all test groups, the numerical values of tear strength for Group VG were statistically lower than Group UGP $(p<0.001)$.

Within Group VG, similar results statistically were detected $(\mathrm{p}=0.246)$. In addition, in Group UGP no statistically significant differences could be determined between the control group, $0.5 \%$ and $1 \% \mathrm{ZrO}_{2}-\mathrm{NPs}$ added test groups $(\mathrm{p}=0.730)$.

In all of the test groups of denture liners, the highest tear strength values were obtained in $0.5 \% \mathrm{ZrO}_{2}-\mathrm{NPs}$ added test groups (TC; $0.58 \pm 0.11 \mathrm{~N}$ and SDL; $4.10 \pm 0.58 \mathrm{~N}$ ). 
Table 3. Mean tear strength values of the tested denture liners

\begin{tabular}{|l|l|l|l|}
\hline & Group VG & Group UGP & p-value $\dagger$ \\
\hline Group 0 (control) & $0.51(0.29)$ & $3.86(1.25)$ & $<\mathbf{0 . 0 0 1}$ \\
\hline Group 1 (0.5\%) & $0.58(0.11)$ & $4.10(0.58)$ & $<\mathbf{0 . 0 0 1}$ \\
\hline Group 2 (1\%) & $0.54(0.11)$ & $3.94(0.28)$ & $<\mathbf{0 . 0 0 1}$ \\
\hline p-value $:$ & 0.246 & 0.730 & \\
\hline
\end{tabular}

Numerical values were expressed as the median (interquartile range), $\uparrow$ by Mann Whitney U test: Considering the added ZrO2-NPs concentration, when Bonferroni correction is applied, $\mathrm{p}<0.0167$ is significantly different, $\ddagger$ by Kruskal-Wallis test: the comparisons among the ZrO2-NPs concentrations for each tested material, when Bonferroni correction is applied, $\mathrm{p}<0.025$ is significantly different.

\subsubsection{Tensile bond strength test}

The mean TBSs for each group of specimens are presented in Table 4. The TBS numerical values of SDL ranged from $1.19 \pm 0.26 \mathrm{MPa}$ to $1.38 \pm 0.44 \mathrm{MPa}$. The TBS results of TC ranged from $0.31 \pm 0.08 \mathrm{MPa}$ to $0.84 \pm 0.23 \mathrm{MPa}$. In the control groups, the difference was not statistically significant between TC and SDL $(\mathrm{p}=0.315)$.

$0.5 \%$ and $1 \% \mathrm{ZrO}_{2}-\mathrm{NPs}$ added SDL test groups (Group UGP1 and Group UGP2) were statistically higher than $0.5 \%$ and $1 \% \mathrm{ZrO}_{2}$-NPs added TC test groups (Group VG1 and Group VG2) (p < 0.001). Group VG1 and Group VG2 showed statistically significantly lower TBS values than TC without $\mathrm{ZrO}_{2}-\mathrm{NPs}$ (Group VG0) $(p<0.001)$. In all of the test groups of SDL, there were statistically similar results $(p=0.239)$.

Table 4. Mean tensile bond strength values of the tested denture liners

\begin{tabular}{|l|l|l|l|}
\hline & Group VG & Group UGP & p-value $\dagger$ \\
\hline Group 0 (control) & $0.84(0.23)^{\mathrm{a}, \mathrm{b}}$ & $1.25(1.54)$ & 0.315 \\
\hline Group 1 (0.5\%) & $0.33(0.06)^{\mathrm{a}}$ & $1.38(0.44)$ & $<\mathbf{0 . 0 0 1}$ \\
\hline Group 2 (1\%) & $0.31(0.08)^{\mathrm{b}}$ & $1.19(0.26)$ & $<\mathbf{0 . 0 0 1}$ \\
\hline p-value $\mathbf{t}$ & $<\mathbf{0 . 0 0 1}$ & 0.239 & \\
\hline
\end{tabular}

Data were expressed as the median (interquartile range), $\dagger$ by Mann Whitney U test: Considering the added ZrO2-NPs concentration, when Bonferroni correction is applied, $\mathrm{p}<0.0167$ is significantly different, $\ddagger$ by Kruskal-Wallis test: the comparisons among the ZrO2-NPs concentrations for each tested material, when Bonferroni correction is applied, $\mathrm{p}<0.025$ is significantly different, a: The difference between control and $0.5 \%$ added $\mathrm{ZrO}_{2}-\mathrm{NPs}$ test materials was statistically significant $(\mathrm{p}<0.001)$, b: the difference between control and $1 \%$ added $\mathrm{ZrO} 2-\mathrm{NPs}$ test materials was statistically significant $(\mathrm{p}<0.001)$.

\subsubsection{Shore A hardness}

The mean for Shore A hardness values of tested groups is shown in Table 5. Statistically, no significant differences were detected between TC and SDL control groups (Group VG0 and Group UGP0) $(\mathrm{p}=0.100)$. The comparisons made between all test groups of SDL, showed no statistically significant differences according to the average hardness values $(\mathrm{p}=0,026)$. In addition, Group VG1, Group VG2, and Group VG0 were not significantly different $(\mathrm{p}=0.061)$. In all test groups of TC and SDL, the highest hardness

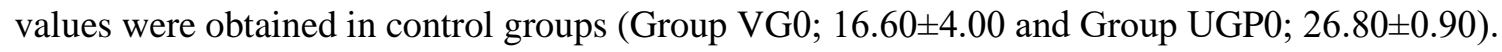


Table 5. Mean shore A hardness values of the tested denture liners

\begin{tabular}{|l|l|l|l|}
\hline & Group VG & Group UGP & p-value $\dagger$ \\
\hline Group 0 (control) & $16.60(4.00)$ & $26.80(0.90)$ & 0.100 \\
\hline Group 1 (0.5\%) & $11.80(2.10)$ & $25.50(0.80)$ & 0.100 \\
\hline Group 2 (1\%) & $12.70(0.70)$ & $26.30(0.30)$ & 0.100 \\
\hline p-value \$ & 0.061 & 0.026 & \\
\hline
\end{tabular}

Numerical values were expressed as the median (interquartile range), $\uparrow$ by Mann Whitney U test: Considering the added ZrO2-NPs concentration, when Bonferroni correction is applied, $\mathrm{p}<0.0167$ is significantly different, $\ddagger$ by Kruskal-Wallis test: the comparisons among the $\mathrm{ZrO} 2-\mathrm{NPs}$ concentrations for each tested material, when Bonferroni correction is applied, $\mathrm{p}<0.025$ is significantly different.

\subsubsection{SEM analysis}

Figure 3 shows the surface morphology of denture liners with and without the $\mathrm{ZrO}_{2}-\mathrm{NPs}$ at two different concentrations. The particle distribution was observed as homogenous, and SEM results of the samples $0.5 \%$ and $1 \% \mathrm{w} / \mathrm{w} \mathrm{ZrO}_{2}$-NPs bearing SDL test groups were similar. No aggregation was observed in these groups and showed successful integration of NPs into the matrix (Figures $3 \mathrm{~b}$ and 3c). However, in TC with combined $0.5 \%$ and $1 \% \mathrm{ZrO}_{2}$-NPs test groups, $\mathrm{ZrO}_{2}-\mathrm{NPs}$ partially agglomeration in the polymer matrix were observed (Figures 3e and 3f). In both $\mathrm{ZrO}_{2}-\mathrm{NPs}$ added test groups, as the nanoparticle ratio increased, the amount of globular-shaped nanoparticles increased throughout the liner matrix (Figures $3 \mathrm{c}$ and $3 \mathrm{f}$ ).
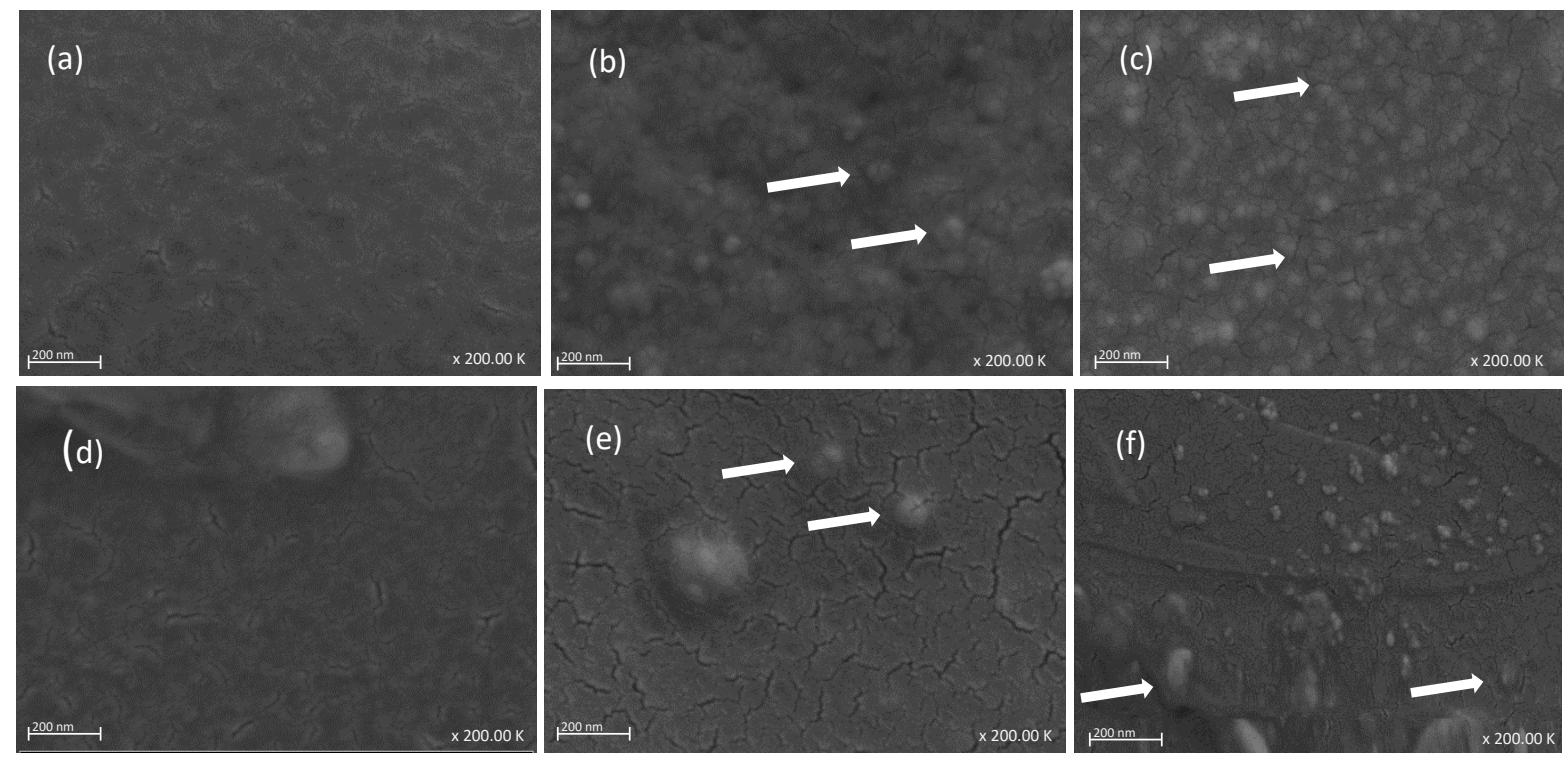

Figure 3. SEM photomicrograph of the tested denture liners

a) SEM micrograph of Group UGPO (without $\mathrm{ZrO}_{2}-\mathrm{NPs}$ )

b) SEM micrograph of Group UGP1 (0.5\% $\mathrm{ZrO}_{2}-\mathrm{NPs}$ added)

c) SEM micrograph of Group UGP2 (1\% $\mathrm{ZrO}_{2}-\mathrm{NPs}$ added)

d) SEM micrograph of Group $\mathrm{VGO}$ (without $\mathrm{ZrO}_{2}-\mathrm{NPS}$ )

e) SEM micrograph of Group VG1 (0.5\% $\mathrm{ZrO}_{2}-\mathrm{NPs}$ added)

f) SEM micrograph of Group VG2 (1\% $\mathrm{ZrO}_{2}-\mathrm{NPs}$ added)

(White arrows show $\mathrm{ZrO}_{2}-\mathrm{NPS}$ ) 


\subsection{Discussion}

Because of the advanced mechanical properties, biocompatibility, and biological properties of $\mathrm{ZrO}_{2}$, it has been widely used nowadays in dental materials [23]. Previous studies suggested the addition of $\mathrm{ZrO}_{2}-\mathrm{NPs}$ into PMMA for improving properties [27, 28]. However, in the literature, there is no study regarding the impacts of $\mathrm{ZrO}_{2}$-NPs incorporation on certain mechanical and physical attributes of denture liners.

The interface adhesion between the polymer and the filler is a crucial factor affecting the polymernanoparticle composite properties [21, 23]. Therefore, SCAs used to modify the surface of $\mathrm{ZrO}_{2}-\mathrm{NPs}$ might eliminate their aggregation and then enhance their integrity with the denture liners [22]. In the present study, $\mathrm{ZrO}_{2}$-NPs powder was added in amounts of $0.5 \%$ and $1 \%$ after modifying with an SCA to achieve the necessary chemical bonds between $\mathrm{ZrO}_{2}-\mathrm{NPs}$ and denture liner. The reason why $\mathrm{ZrO}_{2}-\mathrm{NPs}$ were used at low concentrations in this study was to reduce the cost of nanoparticles and the amount of liquid used in the TC, as well as to enhance other mechanical properties without increasing the hardness of the prosthetic liners. FT-IR analysis is one of the inexpensive and fast spectroscopic techniques. Sample preparation is easy for this analysis. That's why we preferred it for the evaluation of the chemical bond between $\mathrm{ZrO}_{2-}$ NPs and SCA in our study.

The first hypothesis of this research was that the addition of $\mathrm{ZrO}_{2}-\mathrm{NPs}$ improves the TBS and tear strength of various denture liners. In the present study, although there was an increase in tear strength values of $\mathrm{ZrO}_{2}$-NPs added test groups, no statistically significant difference could be determined between the test groups. $0.5 \%$ and $1 \%$ of $\mathrm{ZrO}_{2}$-NPs added TC test groups showed statistically significantly lower TBS values than $\mathrm{TC}$ without $\mathrm{ZrO}_{2}-\mathrm{NPs}$. Thus, the first hypothesis was partially rejected.

It is difficult to determine the tear strength that would be clinically acceptable for short-term or long-term denture liners [29]. However, in line with the results obtained in the current study that the SDL would be much less probably to tear than the TC. The tear strength of silicone-based SDL was found significantly higher compare to the acrylic-based TC among all of the test groups $(\mathrm{p}<0.001)$. This might be due to the presence or absence of the cross-linking agent in tested materials. TCs are composed of uncross-linked amorphous polymers that are formed in situ from the mixture of a polymer powder and a liquid plasticizer. However, silicone-based soft liners have a similar composition to silicone impression materials, both are dimethyl-siloxane polymers $[9,30]$. Polydimethylsiloxane is a viscous liquid that can be cross-linked to form a rubber with good elastic properties [30]. In the present study, statistical results showed that the incorporation of $\mathrm{ZrO}_{2}-\mathrm{NPs}$ into TC and SDL had no unfavorable effect on their tear strength. In addition, in all test groups of TC and SDL, the highest tear strength values were obtained in $0.5 \% \mathrm{ZrO}_{2}-\mathrm{NPs}$ added test groups (TC; $0.58 \pm 0.11 \mathrm{~N}$ and SDL; $4.10 \pm 0.58 \mathrm{~N}$ ).

In previous studies assessing the tear strength, various rates of tearing ranging from $20 \mathrm{~mm} / \mathrm{min}$ to 500 $\mathrm{mm} / \mathrm{min}$ were used $[10,29,31-33]$. The closest tear rate to the oral environment is not clear. However, the SDL and TC are most likely to have been damaged during cleaning procedures which were done with a high rate of force application [34].

The bond quality of TCs and SDLs to denture base has been investigated with various test methods [1, 3537]. The three most usually accepted methods are peel, lap-shear, and tensile tests [1, 14, 35-37]. However, these laboratory tests only let the analysis of one type of material load. Therefore, these tests do not completely reflect the clinical bond strength of various denture liners [14].

SDLs are classified as 'soft' according to the durometer shore A hardness test results. TBS of the material was $1.25 \pm 1.54 \mathrm{MPa}$, which satisfied the requirements of the ISO standard. The TBS of SDL and $\mathrm{ZrO}_{2}$ added SDL (0.5\%; TBS: $1.38 \pm 0.44 \mathrm{MPa}$ and $1 \%$; TBS: $1.19 \pm 0.26 \mathrm{MPa})$ conform to the ISO standard requirements. The bond strength values after the $24 \mathrm{~h}$ soaking process in distilled water were higher than 1 MP among at least 8 out of 10 specimens. Therefore, it can be said that the separation of SDL from the denture base was reduced. Hence, the duration of the clinical use of this material increased. Then, the need 
replacement for these materials, and the costs related to it decrease. Besides, the accumulation of microorganisms will also decrease.

Test variables such as specimen fixation techniques, the arrangement of loading points, and crosshead speed may affect the TBS values [1, 7, 36]. Mutluay and Ruyter [1] performed the TBS test with different denture base materials (Paladon 65, Palapress Vario, Ivocap Plus) at a crosshead speed of $24 \mathrm{~mm} / \mathrm{min}$. The reported TBS values were $1.59 \pm 0.49 \mathrm{MPa}, 1.46 \pm 0.22 \mathrm{MPa}$, and $1.71 \pm 0.43 \mathrm{MPa}$ for Ufi gel Soft. However, in our study the tested materials showed a TBS value of $1.25 \pm 1.54 \mathrm{MPa}, 1.38 \pm 0.44 \mathrm{MPa}, 1.19 \pm 0.26 \mathrm{MPa}$ at a crosshead speed of $10 \mathrm{~mm} / \mathrm{min}$. The difference could be attributed to the crosshead speed. In general, a faster crosshead speed leads to a higher TBS and lower elongation [36]. It has been reported that an adequate bond strength value for denture liners is $0.44 \mathrm{MPa}$ which is acceptable for clinical use $[3,6]$. In our study, the TBS values for all of the SDL groups were higher than $0.44 \mathrm{MPa}$, which were the clinically acceptable bond strength levels. The TBS value of Group VG0 is higher than $0.44 \mathrm{MPa}$, but the $\mathrm{ZrO} 2$ added TCs (Group VG1 and Group VG2) are lower than this value. These results indicate that Groups VG1 and VG2 may increase the likelihood of separation from denture base. Therefore, TCs are recommended for use in clinically shorter periods and cases requiring frequent renewal.

The results obtained from the current study revealed that the addition of $\mathrm{ZrO}_{2}$-NPs into TC decreased the values TBS of test specimens. This finding confirms with SEM photomicrograph of specimens. SEM showed $\mathrm{ZrO}_{2}$-NPs emergence of agglomeration in the polymer matrix for $\mathrm{TC}$ groups, while these nanoparticles were evenly dispersed in SDL groups (Figures 3b,3c 3e, and 3f). For this reason, we might infer that SDL test groups did not negatively affect their TBS values.

The findings of our study display that although there was a slight decrease in hardness values of TC and SDL test groups added with $0.5 \%$ and $1 \% \mathrm{ZrO}_{2}-\mathrm{NPs}$, no meaningful differences found when compared to the control groups, accepting the second hypothesis. During clinical use, TCs and SDLs are predisposed to change in hardness, which is a significant characteristic. The reason is that the higher the softness is, the greater it can absorb the mastication force and impact effects [38]. For this reason, it is desirable to show low hardness values in these materials [39]. The shore A hardness test is commonly opted to determine the elasticity of denture liners [36]. According to the ISO standards, the shore A hardness values of long-term SDL (silicone-based), after $24 \mathrm{~h}$ of aging in distilled water at $37^{\circ} \mathrm{C}$ for soft materials should be between 25 and 50 units. The hardness results of all test subgroups in SDL fulfill the criteria of the ISO standard for long-term denture soft liners (25-50 units).

Chladek et al. [14] stated that increasing the percentage of silver nanoparticles addition reduced the hardness values of the obtained composites. In our study, although there was a slight decrease in hardness values of TC and SDL test groups added with $0.5 \%$ and $1 \% \mathrm{ZrO}_{2}-\mathrm{NPs}$, no statistically significant difference could be detected compared to the control groups (TC, $\mathrm{p}=0.061$; SDL, $\mathrm{p}=0.026$; respectively) The difference from the mentioned work may be due to the type and dosage of the nanoparticle that was used.

Clinically acceptable hardness values for temporarily used soft lining and tissue conditioning materials have not yet been determined. However, Urban et al. [38] reported that Shore A hardness values ranging from 13 to 49 units within $24 \mathrm{~h}$ for these short-term materials were clinically acceptable levels. In our study, the Shore A hardness numerical values for Group VG after kept $24 \mathrm{~h}$ in distilled water (Group VG0:

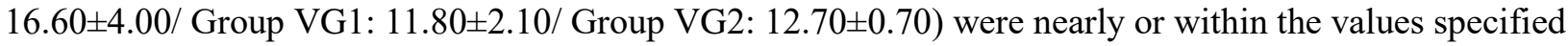
by Urban et al. [38] In addition, it was observed in all the subgroups in TC that the hardness levels were lower than half of the maximum limit (49 units) according to Urban et al. report. From the hardness results standpoint, all of the Group VG was found appropriate for clinical use.

The hardness results of SDL ranged from $25.50 \pm 0.80$ to $26.80 \pm 0.90 \mathrm{MPa}$. The hardness results of TC ranged from $11.80 \pm 2.10$ to $16.60 \pm 4.00$. These various hardness results of tested materials might be connected with differences in their chemical content. Auto-polymerized acrylic-based TCs are mainly comprised of poly ethyl methacrylate resin with a plasticizer like dibutyl phthalate or ethanol [10]. Since 
the plasticizer affects the initial softness of the material [14], loss of plasticizers results in hardening of this material [37]. However, the plasticizer is not necessary to produce softening effects in silicone-based SDLs since their softness is controlled by the amount of cross-linking in the rubber [14, 37].

One of the limitations of our research could be that the test conditions were not similar to those of the oral cavity. Secondly, no aging procedure was performed. In addition, the tensile test was used to measure the bonding strength between various denture liners and denture base material. It is known that SDLs and TCs in the oral cavity are subjected to complex loads; thus, determining the bond strength with a shear or peel test may ensure more information.

\section{CONCLUSIONS}

Within the limitations of the current work, $\mathrm{ZrO}_{2}-\mathrm{NPs}$ addition into the TC affected the TBS adversely but did not negatively affect the tear strength and hardness of these materials. In addition, the incorporation $\mathrm{ZrO}_{2}$-NPs into silicone-based denture liner had no effects with regard to TBS, tear strength, and hardness. All groups of the tested silicone-based denture liners had satisfactory and clinically acceptable bond strength to PMMA denture base. Further research is necessary to investigate the impacts of $\mathrm{ZrO}_{2}-\mathrm{NPs}$ powder with different concentrations on other mechanical and physical properties of various denture liners.

\section{Clinical Relevance}

$\mathrm{ZrO}_{2}-\mathrm{NPs}$ is a useful study in terms of the fact that silicon-based and tissue conditioning materials do not increase the hardness. The stability of hardness can evenly distribute masticatory forces and reduce the absorption of elastic energy. Even though $\mathrm{ZrO}_{2}-\mathrm{NPs}$ addition into the TC led to a lower tensile bond, 5\% $\mathrm{ZrO}_{2}$-NPs addition into silicone-based SDL caused an increase in numerical value (but not statistically significant). If a significant increase in the tensile bond of denture liners by adding optimal $\mathrm{ZrO}_{2}-\mathrm{NPs}$ concentration can be achieved, $\mathrm{ZrO}_{2}$-NPs incorporation to SDL may become a viable method to prevent or reduce separating from denture base.

\section{ACKNOWLEDGEMENTS}

The authors would like to thank the Mersin University Scientific Research Projects Commission for their financial support. The funding of our study is Mersin University Scientific Research Projects Commission (project number 2017-1-AP3-2181).

\section{CONFLICTS OF INTEREST}

No conflict of interest was declared by the authors.

\section{REFERENCES}

[1] Mutluay, M.M., Ruyter, I.E., "Evaluation of bond strength of soft relining materials to denture base polymers", Dental Materials, 23(11): 1373-1381, (2007).

[2] Mancuso, D.N., Goiato, M.C., Zuccolotti, B.C., Moreno, A., dos Santos, D.M., Pesqueira, A.A., "Effect of thermocycling on hardness, absorption, solubility and colour change of soft liners", Gerodontology, 29(2): 215-219, (2012).

[3] Nakhaei, M., Dashti, H., Ahrari, F., Vasigh, S., Mushtaq, S., Shetty, R.M., "Effect of different surface treatments and thermocycling on bond strength of a silicone-based denture liner to a denture base resin", Journal of Contemporary Dental Practice, 17(2): 154-159, (2016).

[4] Tugut, F., Akin, H., Mutaf, B., Akin, G.E., Ozdemir A.K., "Strength of the bond between a silicone lining material and denture resin after Er:YAG laser treatments with different pulse durations and levels of energy", Lasers in Medical Science, 27(2): 281-285, (2012). 
[5] Alaa'a M.S., "Effect of aging on bond strength of two soft lining materials to a denture base polymer", The Journal of Indian Prosthodontic Society, 14(1): 155-160, (2014).

[6] Surapaneni, H., Ariga, P., Haribabu, R., Ravi Shankar, Y., Kumar, V.H., Attili, S., "Comparative evaluation of tensile bond strength between silicon soft liners and processed denture base resin conditioned by three modes of surface treatment: an invitro study", Journal of Indian Prosthodontist Society, 13(3): 274-280, (2013).

[7] Khaledi, A.A., Bahrani, M., Shirzadi, S., "Effect of food simulating agents on the hardness and bond strength of a silicone soft liner to a denture base acrylic resin", The Open Dentistry Journal, 9: 402408, (2015).

[8] Ergun, G., Nagas, I.C., "Color stability of silicone or acrylic denture liners: an in vitro investigation", European Journal of Dentistry, 1(3): 144-151, (2007).

[9] Hashem, M.I., “Advances in soft denture liners: an update”, The Journal of Contemporary Dental Practice, 16(4) : 314-318, (2015).

[10] Landayan, J.I., Manaloto, A.C., Lee, J.Y., Shin, S.W., "Effect of aging on tear strength and cytotoxicity of soft denture lining materials; in vitro", The Journal of Advanced Prosthodontics, 6(2) : 115-120, (2014).

[11] Jaboinski, L.T., Miranda, M.E., Hofling, R.T.B., Pereira, E.C., Pinto, J.R.R., Vasconcellos, A.A.D., "Effect of the addition of propolis on a soft denture liner on bond strength with an acrylic resin", Journal of the Health Sciences Institute, 33(3): 223-227, (2015).

[12] Khanna, A., Bhatnagar, V.M., Karani, J.T., Madria, K., Mistry, S., "Comparative evaluation of shear bond strength between two commercially available heat cured resilient liners and denture base resin with different surface treatments", Journal of Clinical and Diagnostic Research, 9 (5): 30-34, (2015).

[13] Gundogdu, M., Yesil Duymus, Z., Alkurt, M., "Effect of surface treatments on the bond strength of soft denture lining materials to an acrylic resin denture base", Journal of Prosthetic Dentistry, 112(4): 964-971, (2014).

[14] Chladek, G., Kasperski, J., Barszczewska-Rybarek, I., Zmudzki, J., "Sorption, solubility, bond strength and hardness of denture soft lining incorporated with silver nanoparticles", International Journal of Molecular Sciences, 14(1): 563-574, (2012).

[15] Altinci, P., Mutluay, M., Söderling, E., Tezvergil-Mutluay, A., "Antimicrobial efficacy and mechanical properties of BAC-modified hard and soft denture liners", Odontology, 106: 83-89, (2018).

[16] Jain, D., Daima, H.K., Kachhwaha, S., Kothari, S.L., "Synthesis of plant -mediated silver nanoparticles using papaya fruit extract and evaluation of their antimicrobial activities", International Journal of Engineering Science and Technology, 4(1): 557-563, (2009).

[17] Ankanna, S., Prasad, T.N.V.K.V., Elumalai, E.K., Savithramma, N., "Production of biogenic silver nanoparticles using Boswellia ovalifoliolata stem bark", Digest Journal of Nanomaterials and Biostructures, 5(2): 369-372, (2010).

[18] Chladek, G., Mertas, A., Barszczewska-Rybarek, I., Nalewajek, T., Żmudzki, J., Król, W., Łukaszczyk, J., "Antifungal activity of denture soft lining material modified by silver nanoparticlesa pilot study", International Journal of Molecular Sciences, 12(7): 4735-4744, (2011). 
[19] Nam, K.Y., "In vitro antimicrobial effect of the tissue conditioner containing silver nanoparticles", The Journal of Advanced Prosthodontics, 3(1): 20-24, (2011).

[20] Zhang, X.Y., Zhang, X.J., Huang, Z.L., Zhu, B.S., Chen, R.R., "Hybrid effects of zirconia nanoparticles with aluminum borate whiskers on mechanical properties of denture base resin PMMA”, Dental Materials, 33(1): 141-146, (2014).

[21] Asopa, V., Suresh, S., Khandelwal, M., Sharma, V., Asopa, S.S., Kaira, L.S., "A comparative evaluation of properties of zirconia reinforced high impact acrylic resin with that of high impact acrylic resin", Saudi Journal for Dental Research, 6(2): 146-151, (2015).

[22] Gad, M.M., Abualsaud, R., Rahoma, A., Al-Thobity, A.M., Al-Abidi, K.S., Akhtar, S., "Effect of zirconium oxide nanoparticles addition on the optical and tensile properties of polymethyl methacrylate denture base material", International Journal of Nanomedicine, 13: 283-292, (2018).

[23] Gad, M.M., Rahoma, A., Al-Thobity, A.M., ArRejaie, A.S., "Influence of incorporation of $\mathrm{ZrO}_{2}$ nanoparticles on the repair strength of polymethyl methacrylate denture bases", International Journal of Nanomedicine, 11: 5633-5643, (2016).

[24] Keiteb, A.S., Saion, E., Zakaria, A., Soltani, N., "Structural and optical properties of zirconia nanoparticles by thermal treatment synthesis", Journal of Nanomaterials, 1-13, (2016).

[25] Zhou, S., Garnweitner, G., Niederberger, M., Antonietti, M., "Dispersion behavior of zirconia nanocrystals and their surface functionalization with vinyl group-containing ligands", Langmuir, 23: 9178-9187, (2007).

[26] ISO 10139-2-Dentistry-Soft lining materials for removable dentures-Part 2: Materials for long-term use.

[27] Yu, W., Wang, X., Tang, Q., Guo, M., Zhao, J., "Reinforcement of denture base PMMA with $\mathrm{ZrO}_{2}$ nanotubes", Journal of the Mechanical Behavior of Biomedical Materials, 32: 192-197, (2014).

[28] Ahmed, M.A., Ebrahim, M.I., "Effect of zirconium oxide nano-fillers addition on the flexural strength, fracture toughness, and hardness of heat-polymerized acrylic resin", World Journal of Nano Science and Engineering, 4: 50-57, (2014).

[29] Waters, M.G., Jagger, R.G., "Mechanical properties of an experimental denture soft lining material", Journal of Dentistry, 27(3): 197-202, (1999).

[30] Rodrigues, S., Shenoy, V., Shetty, T., "Resilient liners: a review", Journal of Indian Prosthodontist Society, 13(3): 155-164, (2013).

[31] Oguz, S., Mutluay, M.M., Dogan, O.M., Bek, B., "Effect of thermocycling on tensile strength and tear resistance of four soft denture liners", Dental Materials Journal, 26(2): 296-302, (2007).

[32] Santawisuk, W., Kanchanavasita, W., Sirisinha, C., Harnirattisai, C., "Mechanical properties of experimental silicone soft lining materials", Dental Materials Journal, 32(6): 970-975, (2013).

[33] Dootz, E.R., Koran, A., Craig, R.G., "Physical property comparison of 11 soft denture lining materials as a function of accelerated aging", The Journal of Prosthetic Dentistry, 69(1): 114-119, (1993).

[34] Baysan, A., Parker, S., Wright, P.S., "Adhesion and tear energy of a long-term soft lining material activated by rapid microwave energy", The Journal of Prosthetic Dentistry, 79(2): 182-187, (1998). 
[35] Korkmaz, F.M., Bagis, B., Ozcan, M., Durkan, R., Turgut, S., Ates, S.M., "Peel strength of denture liner to PMMA and polyamide: laser versus air-abrasion", The Journal of Advanced Prosthodontics, 5(3): 287-295, (2013).

[36] Kim, B.J., Yang, H.S., Chun, M.G., Park, Y.J., "Shore hardness and tensile bond strength of longterm soft denture lining materials", The Journal of Prosthetic Dentistry, 112(5): 1289-1297, (2014).

[37] Mese, A., Guzel, K.G., "Effect of storage duration on the hardness and tensile bond strength of silicone-and acrylic resin-based resilient denture liners to a processed denture base acrylic resin", The Journal of Prosthetic Dentistry, 99(2): 153-159, (2008).

[38] Urban, V.M., Lima, T.F., Bueno, M.G., Giannini, M., Arioli Filho, J. N., de Almeida, A.L.P., Neppelenbroek, K. H., "Effect of the addition of antimicrobial agents on Shore A hardness and roughness of soft lining materials", Journal of Prosthodontics, 24(3): 207-214, (2015).

[39] Pisani, M.X., da Silva, C.H., Paranhos, H.F., Souza, R.F., Macedo, A.P., "Evaluation of experimental cleanser solution of Ricinus communis: effect on soft denture liner properties", Gerodontology, 29(2): 179-185, (2012). 